\title{
Costing Methods: meta-analysis of articles presented in the Brazilian Congress of Costs over the 1994-2010 period
}

\author{
Métodos de Custeio: uma meta-análise dos artigos apresentados no Congresso \\ Brasileiro de Custos noperíodo de 1994 a 2010
}

\section{Métodos de Costeo: un meta-análisis de artículos presentados en el Congreso Brasileño de Costos en el periodo 1994 a 2010}

\author{
Márcia Zanievicz ${ }^{1}$ \\ Ilse Maria Beuren ${ }^{2}$ \\ Paulo Sérgio Almeida dos Santos ${ }^{3}$ \\ Nilton Roberto Kloeppel ${ }^{4}$
}

Received on August 25, 2011 / Approved on November 14, 2013

Responsible Editor: Ivam Ricardo Peleias, Dr.

Evaluation Process: Double Blind Review

\begin{abstract}
There are many bibliometrics studies that refer to costing methods. However, this research is scattered over the analyzed period, the place of publication and the publishing of the studies analyzed, as well as the longitudinal cut established, amongst other methodological design issues. The goal of this study is to compile and complement bibliometrics studies presented as to Activity Based Costing, Target and Kaizen Costing, Theory of Constraints and of Unity of Effort Production, using the first 17 editions
\end{abstract}

of the Brazilian Congress of Costs (Congresso Brasileiro de Custos/CBC) as a database. Similarly to the methodological path of previous bibliometrics studies on the subject, a descriptive research was carried out alongside a quantitative approach, using the meta-analysis and the content analysis techniques. Results show that there is no regular distribution in articles published over the years, and that Activity Based Costing was the most researched, followed by the Theory of Constraints, and, finally, by Target Costing, Kaizen and Unity of Effort Production together.

1. Doctoral student of Accounting Program at the Regional University of Blumenau (FURB). [marciaza@gmail.com]

2. Doctor in Accounting and Controlling by the University of São Paulo's School of Economics, Business and Accounting (FEA-USP). Professor at Paraná Federal University's Accounting Graduate Program (UFPR). [ilse.beuren@gmail.com] Author's address: Av. Prefeito Lothário Meissner, 632 - Campus III - Jardim Botânico, CEP: 80210-070 - Curitiba - PR - Brazil

3. Master in Accounting by the Regional University of Blumenau. [paulosergio.almeidasantos@gmail.com]

4. Master in Accounting by the Regional University of Blumenau. [niltonkloe@uol.com.br] Authors' address: Rua Antônio da Veiga, 140 - Sala D 202 - Bairro Victor Konder. CEP 89012-900 - Blumenau - SC - Brazil 
Results also indicate that books are still the main source of references for costing methods studies. The nature of the research approached practical and theoretical aspects; however, research focused on the various costing methods that made up the sample did not relate with each other.

Keywords: Meta-analysis. Costing methods. Brazilian Congress of Costs.

\section{RESUMO}

Diversos são os estudos bibliométricos relacionados a métodos de custeio. Tais pesquisas, no entanto, são dispersas em relação ao período de análise, ao local de publicação e socialização dos estudos analisados e ao recorte longitudinal estabelecido, entre outras questóes de desenho metodológico. Assim, o objetivo deste estudo foi compilar e complementar os estudos bibliométricos apresentados sobre Custeio Baseado em Atividades, Custo Meta, Kaizen, Teoria das Restriçóes e Unidade de Esforço de Produção, tendo como base de dados as 17 primeiras ediçóes do Congresso Brasileiro de Custos (CBC). Similar à trajetória metodológica realizada pelos estudos bibliométricos anteriores sobre o tema, realizou-se pesquisa descritiva, com abordagem quantitativa, por meio das técnicas de meta-análise e análise de conteúdo. Os resultados apontaram que não houve distribuição normal no volume de artigos socializados no decorrer dos anos, que o Custeio Baseado em Atividades foi o tema mais pesquisado, seguido da Teoria das Restrições e, por último, apareceram juntos Custo Meta, Kaizen e Unidade de Esforço de Produção. Os achados também indicaram que os livros ainda são as principais fontes de referências dos estudos sobre métodos de custeio. A natureza das pesquisas aproximou-se no tocante aos aspectos prático e teórico; as pesquisas voltadas aos vários métodos de custeio componentes da amostra, porém, não se relacionaram.

Palavras-chave: Meta-análise. Métodos de custeio. Congresso Brasileiro de Custos.

\section{RESUMEN}

Varios estudios bibliométricos se relacionan con métodos de costeo. Sin embargo, estos estudios son imprecisos en relación al período de revisión, lugar de publicación y socialización de los estudios analizados, corte longitudinal, entre otros temas de diseño metodológico. El objetivo de este estudio es recopilar y complementar los estudios bibliométricos presentados en Costeo Basado en Actividades, Costo Meta, Kaizen, Teoría de Restricciones y de la Unidad de Esfuerzo de Producción, sobre la base de datos de las primeras 17 ediciones del Congreso Brasileño de Costos (CBC). Similar a la trayectoria metodológica llevada a cabo por estudios bibliométricos anteriores sobre el tema, la investigación descriptiva se llevó a cabo con un enfoque cuantitativo, usando las técnicas de metaanálisis y análisis de contenido. Los resultados muestran que no hay una distribución normal en el volumen de artículos socializados en los últimos años, que el Costeo Basado en Actividades es el objetivo más buscado, seguido de la Teoría de Restricciones y, finalmente, aparecen juntos el Costo Meta, Kaizen y la Unidad de Esfuerzo de Producción. Los resultados también indican que los libros siguen siendo las principales fuentes de las referencias de los estudios sobre métodos de costeo. La naturaleza de la investigación se acercó en relación a los aspectos teóricos y prácticos, pero la investigación dirigida a los distintos métodos de cálculo de costos componentes de la muestra no están relacionados.

Palabras clave: Meta-análisis. Métodos de costeo. Congreso Brasileño de Costos.

\section{INTRODUCTION}

Management Accounting focuses on meeting the information needs of internal users, defined as the various agents who interact within an organizational context. To fulfill its purpose, it uses a variety of management planning and 
control techniques and tools called Management Accounting artifacts by authors like Oyadomari et al. (2008), Frezatti et al. (2010) and Beuren and Erfurth (2010).

Amongst these Management Accounting artifacts, costing methods are an important tool for the management process and have, over the past decades, increased their capacity for generating information. They inform about issues referring to cost measurement from the perspective of various cost objects, supporting marketing decisions and serving as a communication tool between various organizational stakeholders.

Costing methods' potential for generating information increased maybe because these methodologies became greatly diversified from the twentieth century on. This occurred specially to meet emerging needs resulting mainly from the increased complexity of organizational management, from technological advances and from the media, as well as from the globalization of markets, of economy and of society itself.

In Brazil, from an academic point of view, the increasing importance of Management Accounting and costing methods can be observed, for example, in a permanent forum for discussing and spreading knowledge about this field: the Brazilian Congress of Costs (CBC), was first held in 1994 and every year since then.

Considering that in any field of knowledge there are a number of researchers studying the same fact, it is a challenge for one researcher to assess another who is researching a topic and the way he is doing so. Thus, bibliometric studies are relevant; according to Björneborn and Ingwersen (2004), they are focused on studying the quantitative aspects of production, the dissemination and the use of registered information. To Anderson, Daim and Kim (2008), bibliometrics help researchers produce forecasts and support decision making because it explores, organizes and analyzes large quantities of historical data.

Specifically, there are several bibliometric studies concerning Costing Methods, such as: Callado and Almeida (2005); Lucena, Freire and Brito (2010); Diehl and Souza (2008); Cruz et al. (2010), Walter et al. (2009), Clemente et al. (2010); and Rocha, Wienhage and Scarpin (2010). These studies, however, are dispersed as to the period of analysis, the place where the analyzed studies were published and the longitudinal cut that was established, amongst other issues referring to methodological design.

In a survey carried out in five major national events, we observed that over 140 bibliometric studies were presented in recent years. Decentralization of these surveys, or even the fact that they were carried out without any proper preoccupation with supplementing or enhancing previously published studies, ended up weakening their goal, which was, amongst other things, according to Anderson, Daim and Kim (2008), to help researchers in preparing forecasts and supporting decision making.

Thus, we came up with the following research question: How can the bibliometric studies referring to Activity Based Costing, Target and Kaizen Costing, Theory of Constraints and Unity of Effort Production, all presented in the first 17 editions of the Brazilian Congress of Costs, be described? In this way, this research aims at compiling and complementing bibliometric studies about Activity Based Costing, Target and Kaizen Costing, Theory of Constraints and Unity of Effort Production, based on data from the first 17 editions of the Brazilian Congress of Costs.

The relevance of this research is the possibility of compiling, in a single paper, data on the evolution of articles presented and of the literature database for the construction of research, of authors and institutions, from the first edition of the CBC on. Research of this nature, despite its relevance to new researchers, is not common in bibliometric studies in the accounting field, due to the longitudinal and cumulative perspective of all editions of the CBC up to its 17 th edition.

This research is also justified by the growing interest in characterizing accounting and its ramifications in Brazil. According to Andrade and Muÿlder (2010, p. 2), “[...] it is 
extremely important to pay attention to the academic discussion concerning the evolution of accounting in Brazil, raising evidences, trends and potential, and thus allowing for reflection on the performance of articles in the annals of conferences and journals". In this study, we focus on Cost Accounting, specifically on costing methods.

\section{COST ACCOUNTING AND COSTING METHODS}

One of the principles of Cost Accounting is that different needs may require different information. Information generated by Cost Accounting contributes to the continuous improvement of production processes, to quality and productivity management, to environmental management and to marketing decisions, and also helps planning, control and strategic decision making. Not all information required by an entity may be obtained, however, because cost information can always be improved; the best decision regarding the type of information obtained must, nonetheless, take into account the cost of obtaining it (MAHER, 2001; HANSEN, MOWEN, 2001).

Different costing methods can be used for different cost objects and information purposes. To Hansen and Mowen (2001), a cost object is any item for which costs are measured and to which they are assigned. Accuracy in allocating costs to the cost object is desirable; due to the difficulty in tracking the costs of these objects, however, the idea of true cost is underlying and refers to the rationality and logic of cost allocation methods that are being used.

There are various cost allocation methods available in literature (MARTINS; ROCHA, 2010), used individually or together. These methods, in most cases, are distinguished from each other by the way they track costs, which can be direct, step-down or reciprocal. The first is the most accurate, but does not cover most of the costs that are common to several other cost objects; step-down is based on the cause-effect relationship, providing better quality of information compared to that tracked by reciprocal, which is cheaper to operate.

Amongst costing methods discussed in literature we can point out Absorption Costing, Variable Costing, Direct Costing, Activity Based Costing and Target Costing. We also sometimes observe the Theory of Constraints and the Kaizen as belonging to that category. It is noteworthy that there is no uniformity in literature about their names and classification; they are sometimes called principles, methods, artifacts, instruments, tools or techniques. In this study, we chose to use "costing methods", since in the researched bibliometric studies this was the term most commonly used to describe them.

\section{BIBLIOMETRIC STUDIES}

Bibliometric research is made up of a set of laws and principles from information science. Its main function is to investigate the quantitative aspects of production, the dissemination and use of recorded information and, thus, contribute to the assessment of the current state of this science, facilitate its management and draw a profile of a particular scientific field (MACIAS-CHAPULA, 1998; ARAÚJO, 2006 ; NORONHA, MARICATO, 2008). Moreover, according to Guedes and Borschiver (2005), bibliometrics is a statistical tool that allows one to map and generate different indicators of management treatment for information and knowledge.

According to Araújo (2006, p. 12), bibliometric research is "the application of statistical and mathematical techniques to describe aspects of literature and of other media (quantitative analysis of information)". Bibliometrics, according to Hood and Wilson (2001), are useful for analyzing previously published studies.

To Borschiver and Guedes (2005), there are several laws of bibliometrics, each with a specific assignment. The most commonly used laws are: Bradford, which deals with the productivity of journals; Lotka, which deals with 
the scientific productivity of authors; and Zipf, which deals with the frequency of words. For this research, we used Zipf's Law, because words are the focus of this study.

\section{I Meta-analysis}

According to Hunter and Schmidt (2004), meta-analysis is a technique that allows accurate integration of findings from previous studies on a specific topic, so as to assess the overall effect of studies. To Lovatto et al. (2007), "meta-analysis is a procedure that combines results from several studies to produce a reproducible and quantifiable data synthesis".

Lovatto et al. (2007) report that the foundations of meta-analysis come from the statistical method for combining p-values, proposed by Fisher (1935), and that the first research interested in combining several results from independent experiments was carried out by Cochran (1954). According to Riera, Abreu and Ciconelli (2006), however, the first meta-analysis was published in 1904, in the British Medical Journal.

The contemporary vision of meta-analysis, to Riera, Abreu and Ciconelli (2006) and Lovatto et al. (2007), was first applied by Glass (1976), followed by other scholars such as Smith and Glass (1977), Schmidt and Hunter (1977), Rosenthal (1978), Cooper and Rosenthal (1980) and Hedges and Olkin (1985). It is, therefore, a relatively new technique for analysis and compilation of data (LOVATTO et al., 2007; OSWALD, PLONSKY, 2010).

Meta-analysis has evolved well in certain fields of knowledge, and its relevance is in the collaborative power of researchers, because its findings produce greater theoretical quality and better empirical results than an isolated set of primary studies. We must highlight the medical field, which even harbors a virtual database (http://cochrane.bvsalud.org). This database, in its first version, from 2005 , contained 435,786 randomized trials, with free access, available to other employees, and certainly contributed to the bounty of meta-analysis studies (RIERA, ABREU, CICONELLI, 2006).
According to Lovatto et al. (2007) and Oswald and Plonsky (2010), meta-analysis' biggest difficulty is in selecting the previous studies to be included in research, since this selection directly influences variables to be analyzed. That is, the quality of meta-analysis depends on the quality of primary research.

\subsection{Previous bibliometric studies}

In general, over the $1996-2000$ period, according to Hood and Wilson (2001), the rate of publication of bibliometric studies, alongside other techniques for metric analysis of publications, was of an average 300 publications a year.

Amongst the many bibliometric studies in the accounting field, for example, there is the study by Hesford et al. (2006), who, in a 20-year longitudinal cut, researched Management Accounting in ten journals in English, revealing, amongst other things, the theoretical focus of research, the methodology, the number of published articles and the most cited authors. In turn, Baxter and Chua (2003) analyzed 23 years of the Accounting, Organizations and Society (AOS) magazine, addressing in it alternative theories.

In Brazil there are several bibliometric studies from the accounting field, divulged in conferences and published in journals. These studies are important for many reasons; one of them is the possibility that, through them, we have a consultation base referring to the state of the art of a given topic, allowing us to check for gaps in knowledge generation, researchers and institutions engaged in the theme and to analyze the evolution of the theoretical basis that supports these studies, amongst other aspects.

As for presentations, according to a survey of major Business and Accounting conferences websites', in Brazil, we observed that over 140 bibliometric studies were carried out, highlighting the relevance of this research nationally, as well.

Concerning bibliometric studies in the Cost Accounting field, we identified items presented in the following Brazilian events: the ANPCONT Congress, the Brazilian Congress of 
Costs (CBC), the USP Congress of Accounting and Controlling, the ANPAD Meeting (EnANPAD), the Education and Research in Business and Accounting Meeting (EnPEQ), the National Conference of Production Engineering (ENEGEP) and the National Meeting of Business Management and the Environment (Engema).
In Chart 1, we present bibliometric studies identified at these scientific events that we considered most relevant to costing methods pointed out in the goal of this study, highlighting authors, events, the costing topic and their scope.

\begin{tabular}{|c|c|c|c|}
\hline Authors & Event & Topic (field) & Scope \\
\hline $\begin{array}{l}\text { Schultz et al. } \\
(2006)\end{array}$ & $\begin{array}{l}\text { USP Congress of } \\
\text { Accounting and } \\
\text { Controlling }\end{array}$ & Costing in the services field & $\begin{array}{l}\text { Publications classified as A and B by Qualis. } \\
\text { Fields of Management and Tourism and } \\
\text { EnAnpad annals. } \\
\text { Period: } 2000-2004 .\end{array}$ \\
\hline Diehl and Souza (2007) & $\mathrm{CBC}$ & Activity Based Costing - $\mathrm{ABC}$ & $\begin{array}{c}\text { CBC. } \\
\text { Period: } 1997-2006\end{array}$ \\
\hline $\begin{array}{l}\text { Lucena; Freire; Brito } \\
(2010)\end{array}$ & $\mathrm{CBC}$ & Costing in hospitals & $\begin{array}{l}\text { USP Congress Annals. } \\
\text { Period: 2001-2007 }\end{array}$ \\
\hline Cruz et al. (2009) & $\mathrm{CBC}$ & Theory of Constraints - TOC & $\begin{array}{c}\text { CBC. } \\
\text { Period: } 1994-2008\end{array}$ \\
\hline $\begin{array}{l}\text { Oliveira; Carvalho; } \\
\text { Gomes (2009) }\end{array}$ & $\mathrm{CBC}$ & $\begin{array}{c}\text { Costs and Management } \\
\text { Accounting }\end{array}$ & $\begin{array}{l}\text { Capes, whose data comes from master's and } \\
\text { doctoral programs in Accounting. } \\
\text { Period: } 2004-2006 \text { triennium. }\end{array}$ \\
\hline $\begin{array}{l}\text { Oliveira; Carvalho; } \\
\text { Gomes (2009) }\end{array}$ & ENEGEP & $\begin{array}{c}\text { Cost and Management } \\
\text { Accounting }\end{array}$ & $\begin{array}{l}\text { Capes Cadernos de Indicadores. } \\
\text { Period: 2004-2006 triennium. }\end{array}$ \\
\hline Walter et al. (2009) & $\mathrm{CBC}$ & $\begin{array}{c}\text { Unity of Effort Production - } \\
\text { UEP }\end{array}$ & $\begin{array}{l}\text { CBC and Enegep. } \\
\text { Period: 1994-2008. }\end{array}$ \\
\hline Rocha et al. (2010) & $\mathrm{CBC}$ & Research in the field of Costs & $\begin{array}{c}\text { EnAnpad. } \\
\text { Period: } 1997-2008 .\end{array}$ \\
\hline $\begin{array}{l}\text { Rocha; Scarpin; } \\
\text { Wienhage (2010) }\end{array}$ & ENEGEP & Target and Kaizen Costing & $\begin{array}{c}\text { CBC. } \\
\text { Period: } 2002-2009 .\end{array}$ \\
\hline
\end{tabular}

CHART 1 - Bibliometric Studies about costing methods and Management Accounting

Source: Research data.

\section{RESEARCH METHOD AND PROCEDURES}

Similarly to the design of other bibliometric studies, in this study we carried out descriptive research with a quantitative approach. We focused on this design since, in research, the goal is to obtain information about the characteristics of scientific production referring to costing methods. A longitudinal study was carried out, with 17-year cutout, of the Brazilian Congress of Costs (CBC). To implement research, we used the document research technique, and for data analysis we used meta-analysis and content analysis.
Since the goal of this study was to compile into a single publication research divulged in the first 17 editions of CBC, using costing methods as a central topic, the first definition to be made was which costing methods to compile. The criterion used was to research costing methods that had already been the subject of previous bibliometrics studies and, in this way, complement them and compile them into a single study, based on meta-analysis. To this end, we used the following studies as basis: Diehl and Souza (2008), Cruz et al. (2009), Walter et al. (2009), and Rocha, Wianhage and Scarpin (2010). 
As reported by Oswald and Plonsky (2010), one of the most important tasks in carrying out meta-analysis is selecting the studies that will be the basis for research, that is, the studies that will be incorporated into this new research. The investigated variables in the new research depend on their existence in the previous study; this is an important limitation of the research.
With regard to what information to compile, given the need to analyze variables that are common to all studies, we considered as criterion for establishing them the existence of any such information in the four studies used as basis. Chart 2 presents, in summary form, information that was extracted from these previous studies.

\begin{tabular}{|c|c|c|c|c|}
\hline Variable & $\mathrm{ABC}$ & $\mathrm{CM} / \mathrm{CK}$ & UEP & TOC \\
\hline Reference analysis & - & Yes & Yes & Yes \\
\hline Most prolific authors & Yes & Yes & Yes & Yes \\
\hline Topic focus & - & - & Yes & Yes \\
\hline Authors' education & - & - & Yes & - \\
\hline Gender of researcher & - & - & - & Yes \\
\hline Nature of study & Yes & Yes & Yes & Yes \\
\hline Most cited publications & Yes & - & - & - \\
\hline Words most often used in title & Yes & - & - & - \\
\hline Period of collection & $1997-2006$ & $2002-2009$ & $1994-2008$ & $1994-2008$ \\
\hline Amount of articles over period & Yes & Yes & Yes & Yes \\
\hline Author's (demographic) region & - & - & Yes & Yes \\
\hline Authors' titling & - & - & Yes & - \\
\hline $\begin{array}{l}\text { Connection with higher education } \\
\text { institution }\end{array}$ & - & - & Yes & Yes \\
\hline
\end{tabular}

Caption: Activity Based Costing (ABC), Target Costing (CM) and Kaizen Costing (CK), Unity of Effort Production (UEP) and Theory of Constraints (TOC).

CHART 2 - Analysis of topics addressed by previous studies

Source: Research data.

We noted that, as described by Lovatto et al. (2007) and Oswald and Plonsky (2010), the occurrence of common variables that favor the realization of meta-analysis is a problem. This fact can be seen in the variability of data collected in each of the studies described in Chart 2. We noted that they differ significantly with respect to the type of data collection carried out, a factor that hinders their compilation into a single analysis. Thus, in this study, variables collected are those that are shaded in Chart 2, namely: reference analysis, most prolific authors and number of articles per period, for the 1994-2010 period.

Another relevant factor is that the studies used as basis to research cover different periods of data collection. To make it possible to obtain a longitudinal analysis of all CBC editions, we proceeded to collect the missing data in each study, namely:

a) ABC topic - additional collection from 1994 to 1996 and from 2007 to 2010 ;

b) CM/CK topic - additional collection from 1994 to 1993 and from 2009 and 2010;

c) UEP topic - collection from 2009 and 2010;

d) TOC topic - collection from 2009 and 2010.

We noted that the collection of additional data was implemented by typing, in the CBC website, the same search words used in the initial articles on which this research is based. 
Although the bibliometric research that addressed Activity Based Costing did not include reference analysis, information that was considered important in other studies, we chose to include it in this study, and as such it had to be collected over all study periods.

Having established the costing methods to be studied and the analysis variables (references, most prolific authors, nature of study, period of data collection and amount of articles published over period), we proceeded to analyze the data collected in this research.

\section{ANALYSIS AND INTERPRETATION OF RESULTS}

Table 1 shows the distribution of research on costing methods presented and divulged at the Brazilian Congress of Costs over the 1994-2010 period. Note that the compilation in Table 1 was preceded by the research of Diehl and Souza (2008); Cruz et al. (2010); Walter et al. (2009); and Rocha, Wienhage and Scarpin (2010).

TABLE 1 - Articles on costing methods presented in the Brazilian Congress of Costs over the 1994-2010 period

\begin{tabular}{|c|c|c|c|c|c|c|c|c|}
\hline \multirow{2}{*}{ Period } & \multicolumn{4}{|c|}{ Absolute frequency } & \multicolumn{4}{|c|}{ Relative frequency (\%) } \\
\hline & $\mathrm{ABC}$ & CM/CK & UEP & TOC & $\mathrm{ABC}$ & $\mathrm{CM} / \mathrm{CK}$ & UEP & TOC \\
\hline 1994 & 8 & 1 & 2 & 1 & 2.88 & 2.50 & 5.00 & 1.89 \\
\hline 1995 & 18 & 1 & 4 & 1 & 6.47 & 2.50 & 10.00 & 1.89 \\
\hline 1996 & 8 & 0 & 1 & 0 & 2.88 & 0.00 & 2.50 & 0.00 \\
\hline 1997 & 11 & 1 & 0 & 3 & 3.96 & 2.50 & 0.00 & 5.66 \\
\hline 1998 & 5 & 2 & 1 & 3 & 1.80 & 5.00 & 2.50 & 5.66 \\
\hline 1999 & 15 & 2 & 2 & 6 & 5.40 & 5.00 & 5.00 & 11.32 \\
\hline 2000 & 22 & 3 & 1 & 4 & 7.91 & 7.50 & 2.50 & 7.55 \\
\hline 2001 & 16 & 2 & 1 & 2 & 5.76 & 5.00 & 2.50 & 3.77 \\
\hline 2002 & 21 & 3 & 0 & 0 & 7.55 & 7.50 & 0.00 & 0.00 \\
\hline 2003 & 19 & 1 & 1 & 3 & 6.83 & 2.50 & 2.50 & 5.66 \\
\hline 2004 & 17 & 3 & 3 & 5 & 6.12 & 7.50 & 7.50 & 9.43 \\
\hline 2005 & 34 & 4 & 6 & 11 & 12.23 & 10.00 & 15.00 & 20.75 \\
\hline 2006 & 17 & 2 & 3 & 2 & 6.12 & 5.00 & 7.50 & 3.77 \\
\hline 2007 & 19 & 3 & 2 & 3 & 6.83 & 7.50 & 5.00 & 5.66 \\
\hline 2008 & 21 & 6 & 4 & 3 & 7.55 & 15.00 & 10.00 & 5.66 \\
\hline 2009 & 17 & 1 & 3 & 5 & 6.12 & 2.50 & 7.50 & 9.43 \\
\hline 2010 & 10 & 5 & 6 & 1 & 3.60 & 12.50 & 15.00 & 1.89 \\
\hline Total & 278 & 40 & 40 & 53 & 100.00 & 100.00 & 100.00 & 100.00 \\
\hline Average & 16 & 2 & 3 & 3 & & & & \\
\hline Standard Deviation & 7 & 2 & 2 & 3 & & & & \\
\hline
\end{tabular}

Caption: Activity Based Costing (ABC), Target Costing (CM) and Kaizen Costing (CK), Unity of Effort Production (UEP) and Theory of Constraints (TOC).

Source: Research data. 
As shown in Table 1, in the study period there were a total 411 surveys about costing methods presented and divulged in the Brazilian Congress of Costs. Of this total, over $60 \%$ was research on the $\mathrm{ABC}$ costing method, whereas the other methods together accounted for less than $50 \%$ of the papers presented at the event, as seen

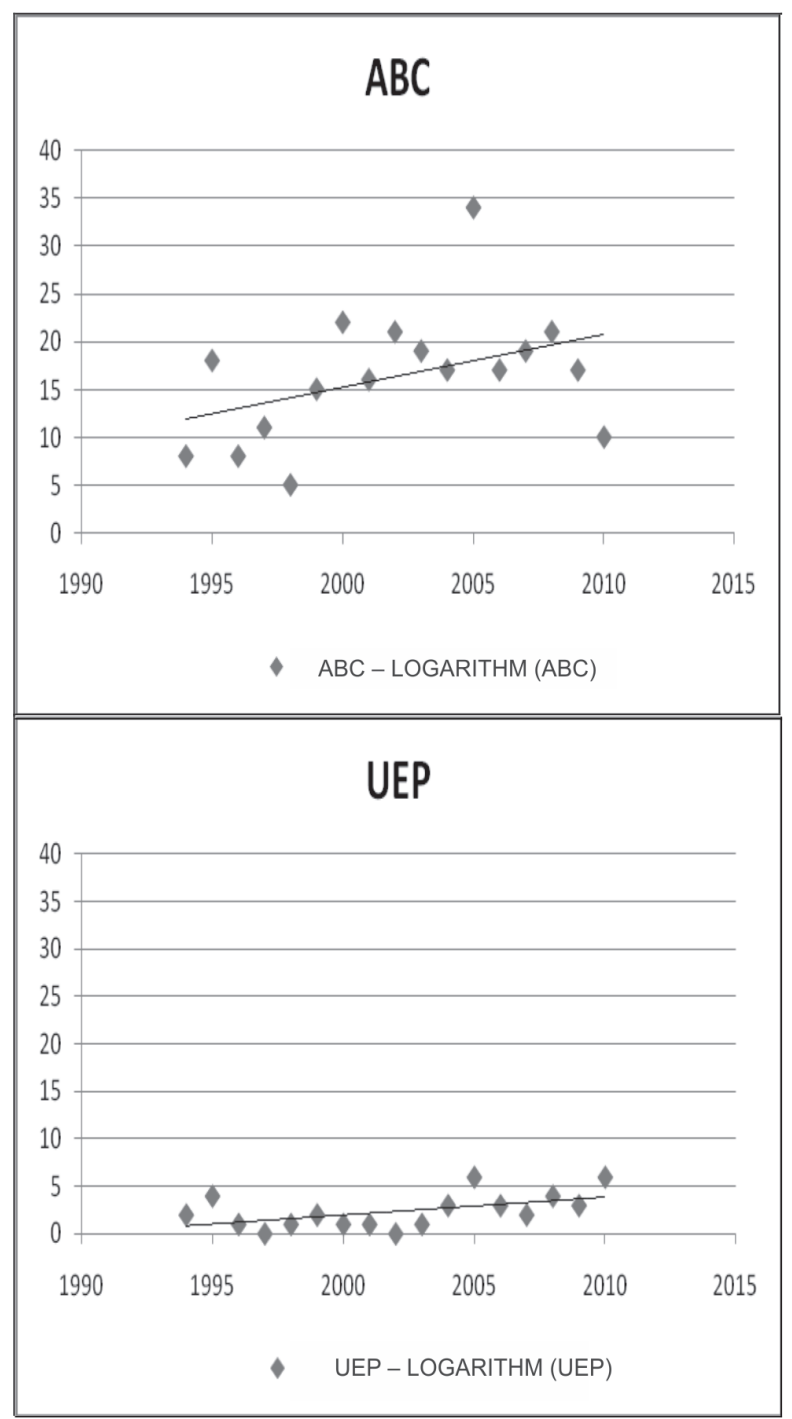

FIGURE 1 - Trend analysis

Source: Research data.

We can see, in Figure 1, that all the analyzed topics showed a growth trend. $A B C$ costing is the one with the highest growth trend, but is also the most dispersed amongst submissions over the analyzed period. On the other hand, the other costing methods, together, in the average of articles submitted. Please note that 2005 was the year with the highest number of submissions of articles on costing methods, according to relative frequency in Table 1.

Figure 1 presents a visual analysis of the trend of articles referring to each of the costing methods analyzed.

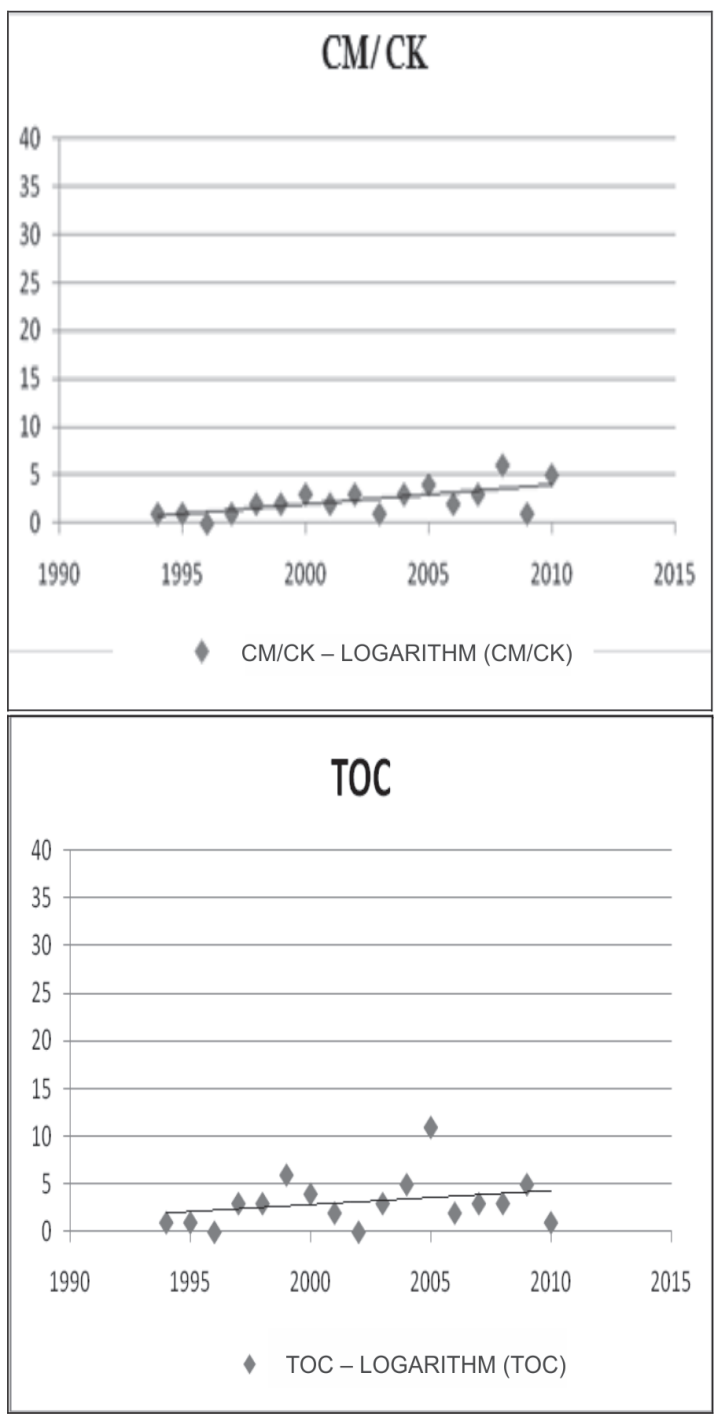

presented some similarity as to the rate of their growth trend. Finally, divulged studies referring to Target Costing, Kaizen Costing and UEP methods were those with smallest dispersion in submissions over the analyzed period. 
Table 2 lists the most prolific authors in research concerning the $\mathrm{ABC}$ costing method, presented and divulged in the Brazilian Congress of Costs over the 1994-2010 period.

TABLE 2 - Most prolific authors in research concerning the ABC costing method, presented and divulged in the Brazilian Congress of Costs over the 1994-2010 period

\begin{tabular}{lcccc}
\hline Author & Institution & Absolute frequency & $\begin{array}{c}\text { Relative } \\
\text { frequency (\%) }\end{array}$ & Total frequency (\%) \\
\hline SOUZA, A. A. & UFMG & 13 & 20.97 & 4.68 \\
COGAN, S. & UFRJ & 11 & 17.74 & 3.96 \\
PAMPLONA, E. O. & EFEI & 10 & 16.13 & 3.60 \\
LIMA, P. C. & UNICAMP & 9 & 14.52 & 3.24 \\
BEZERRA, F. A. & FURB & 7 & 11.29 & 2.52 \\
BORNIA, A. C. & UFSC & 6 & 9.68 & 2.16 \\
RAIMUNDINI, S. L. & UFRGS & 6 & 9.68 & 2.16 \\
Total & & 62 & 100.00 & 22.30 \\
\hline
\end{tabular}

Caption: Federal University of Minas Gerais (UFMG); Federal University of Rio de Janeiro (UFRJ); Federal College of Itajubá (EFEI); University of Campinas( Unicamp); Regional University of Blumenau (FURB); Federal University of Santa Catarina (UFSC); Federal University of Rio Grande do Sul (UFRGS).

Source: Research data.

In Table 2, we can observe that, in scientific production referring to $\mathrm{ABC}$, the author with most research focused on the topic is A. A. Souza (UFMG), with a total 13 papers submitted over the period. Next come authors Samuel Cogan (UFRJ), with 11 articles; Edson Pamplona (EFEI), with 10 articles; Paulo Corrêa Lima (Unicamp), with 9 articles; Francisco Antonio Bezerra (FURB), with 7 articles; Antonio Cezar Bornia (UFSC), with 6 articles; and S. L. Raimundini (UFRGS), with six articles. These results differ from those shown previously by Diehl and Souza (2008), possibly due to a change in the scientific production of these researchers over the analyzed periods. We also observed that these seven most prolific researchers are responsible for $22.30 \%$ of articles about Activity Based Costing presented in the CBC over the 1994-2010 period.

In Table 3 are listed the most prolific authors in research about Target and Kaizen Costing presented and divulged in the Brazilian Congress of Costs over the 1994-2010 period.

TABLE 3 - Most prolific authors in research concerning Target and Kaizen Costing, presented in the Brazilian Congress of Costs over the 1994-2010 period

\begin{tabular}{lcccc}
\hline \multirow{2}{*}{ Author } & Institution & Absolute frequency & $\begin{array}{c}\text { Relative frequency } \\
\text { (\%) }\end{array}$ & $\begin{array}{c}\text { Total frequency } \\
(\%)\end{array}$ \\
\hline ROCHA, W. & USP & 7 & 38.89 & 17.50 \\
BEUREN, I. M. & FURB & 4 & 22.22 & 10.00 \\
PETER, M. G. A. & UFC & 3 & 16.67 & 7.50 \\
CAMACHO, R. R. & UEM & 2 & 11.11 & 5.00 \\
SCARPIN, J. E. & FURB & 2 & 11.11 & 5.00 \\
Total & & 18 & 100.00 & 45.00 \\
\hline
\end{tabular}

Caption: University of São Paulo (USP); Regional University of Blumenau (FURB); Federal University of Ceará (/UFC); Maringá State University (UEM).

Source: Research data. 
In Table 3, we can observe that, in scientific production referring to Target and Kaizen Costing, the author with most research focused on the topic is Welington Rocha (University of São Paulo), with a total seven papers presented over the period. Next come authors Ilse M. Beuren (FURB), with four articles; Maria G. A. Peter (UFC), with three articles; and, with two articles, Reinaldo R. Camacho (EMU) and George E. Scarpin (FURB). These results comply with the findings of Rocha, Wienhage and Scarpin (2010). We also emphasize that these five most productive researchers account for $45 \%$ of articles on Target and Kaizen Costing presented at the CBC over the 1994-2010 period.

Table 4 presents the most prolific authors in research concerning the Unity of Effort Production (UEP) costing method, presented and divulged at the CBC over the 1994-2010 period.

TABLE 4 - Most prolific authors in research concerning the Unity of Effort Production (UEP) method, presented in the Brazilian Congress of Costs over the 1994-2010 period

\begin{tabular}{lcccc}
\hline \multirow{2}{*}{ Author } & Institution & $\begin{array}{c}\text { Absolute } \\
\text { frequency }\end{array}$ & $\begin{array}{c}\text { Relative frequency } \\
(\%)\end{array}$ & $\begin{array}{c}\text { Total frequency } \\
(\%)\end{array}$ \\
\hline WERNKE, R. & UNISUL & 6 & 25.00 & 15.00 \\
KLIEMANN NETO, F. J. & UFRGS & 5 & 20.83 & 12.50 \\
LEMBECK, M. & UNISUL & 5 & 20.83 & 12.50 \\
BORGERT, A. & UFSC & 4 & 16.67 & 10.00 \\
BORNIA, A. C. & UFSC & 4 & 16.67 & 10.00 \\
Total & & 24 & 100.00 & 60.00 \\
\hline
\end{tabular}

Caption: Federal University of Rio Grande do Sul (UFRGS); Federal University of Santa Catarina (UFSC); South Santa Catarina University (UNISUL).

Source: Research data.

In Table 4, we can observe that, in scientific literature concerning the Unity of Effort Production (UEP) method, the author with most research focused on the topic is Rodney Wernke (UNISUL), with a total six articles presented over the period. Next come the following authors: Francisco J. Kliemann Neto (UFRGS) and Marluce Lembeck (UNISUL), with five articles each; Altair Borgert (UFSC) and Antonio C. Bornia (UFSC), both with four articles on the topic. These results comply with the research findings of Walter et al. (2009). These five most prolific researchers account for $60 \%$ of presentations on the Unity of Effort Production method at CBC over the 1994-2010 period.

In Table 5, we show the most prolific authors in research concerning the Theory of Constraints (TOC) method, presented in the Brazilian Congress of Costs over the 1994-2010 period.

TABLE 5 - Most prolific authors in research concerning the Theory of Constraints (TOC) method, presented in the Brazilian Congress of Costs over the 1994-2010 period

\begin{tabular}{lcccc}
\hline Author & Institution & $\begin{array}{c}\text { Absolute } \\
\text { frequency }\end{array}$ & $\begin{array}{c}\text { Relative } \\
\text { frequency (\%) }\end{array}$ & $\begin{array}{c}\text { Total frequency } \\
\text { (\%) }\end{array}$ \\
\hline COGAN, S. & UFRJ & 13 & 33.33 & 24.53 \\
CIA, J. N. S. & USP & 5 & 12.82 & 9.43 \\
ROCHA NETO, A. & UFSC & 4 & 10.26 & 7.55 \\
CIA, J. C. & MACKENZIE & 3 & 7.69 & 5.66 \\
Total & & 39 & 100.00 & 73.58 \\
\hline
\end{tabular}

Caption: Federal University of Rio de Janiero (UFRJ); University of São Paulo (USP); Mackenzie Presbiterian University (Mackenzie); Federal University of Santa Catarina (UFSC).

Source: Research data. 
In Table 5, we can observe that, in scientific literature concerning the Theory of Constraints (TOC) method, the author with most research focused on the topic is Samuel Cogan (UFRJ), with a total 13 papers presented over the period. Next come the following authors: Joanília N. S. Cia (USP), with five articles; Anselmo Rocha Neto (UFSC) and Josilmar C. Cia (Mackenzie), with four and three papers, respectively, about the topic over the highlighted years. These results comply with the research findings of Cruz et al. (2009). These four most productive researchers account for $73.58 \%$ of the presentations concerning the Theory of Constraints at CBC over the 19942010 period.

The nature of research on costing methods, presented and divulged at the Brazilian Congress of Costs over the 1994-2010 period, is shown in Table 6. It presents the absolute and relative frequency of each costing method.

TABLE 6 - Nature of research on costing methods, presented and divulged at the Brazilian Congress of Costs over the 1994-2010 period

\begin{tabular}{lcccccccc}
\hline \multirow{2}{*}{ Nature of research } & \multicolumn{4}{c}{ Absolute frequency } & \multicolumn{4}{c}{ Relative frequency (\%) } \\
\cline { 2 - 22 } & ABC & CM/CK & UEP & TOC & ABC & CM/TC/CK & UEP & TOC \\
\hline Practical & 172 & 22 & 19 & 29 & 61.87 & 53.66 & 47.50 & 54.72 \\
Theoretical & 106 & 19 & 21 & 24 & 38.13 & 46.34 & 52.50 & 45.28 \\
Total & 278 & 41 & 40 & 53 & 100.00 & 100.00 & 100.00 & 100.00 \\
\hline
\end{tabular}

Caption: Activity Based Costing (ABC), Target Costing (CM), Unity of Effort Production (UEP), Theory of Constraints (TOC) and Kaizen Costing (CK).

Source: Research data.

We can observe, in Table 6, that there is a closer relationship between practical and theoretical studies, with the exception of research on the ABC method. This means that the authors attempt, through literature, to explain the findings of their practical work, although almost all of the research focused on costing methods, as seen in the data collection, does not offer a theoretical base. The balance between practical and theoretical studies has already been identified in previous studies.

In Table 7 are presented the main types of references of research on costing methods presented in the Brazilian Congress of Costs over the 1994-2010 period.

TABLE 7 - Main references of research on costing methods presented in the Brazilian Congress of Costs over the 1994-2010

\begin{tabular}{lcccccccc}
\hline \multirow{2}{*}{ Bibliographic references } & \multicolumn{4}{c}{ Absolute frequency } & \multicolumn{5}{c}{ Relative frequency (\%) } \\
\cline { 2 - 9 } & ABC & CM/CK & UEP & TOC & ABC & CM/CK & UEP & TOC \\
\hline Sites/Web & 104 & 15 & 13 & 31 & 2.47 & 2.29 & 2.54 & 3.57 \\
Books & 2,451 & 355 & 267 & 456 & 58.15 & 54.28 & 52.25 & 52.53 \\
Scientific event annals & 356 & 45 & 92 & 109 & 8.45 & 6.88 & 18.00 & 12.56 \\
Dissertations/Thesis & 274 & 79 & 59 & 42 & 6.50 & 12.08 & 11.55 & 4.84 \\
National journals & 253 & 31 & 67 & 212 & 6.00 & 4.74 & 13.11 & 24.42 \\
International journals & 777 & 129 & 13 & 18 & 18.43 & 19.72 & 2.54 & 2.07 \\
Total & 4,215 & 654 & 511 & 868 & 100.00 & 100.00 & 100.00 & 100.00 \\
\hline Average references by article & 15 & 16 & 12 & 16 & & & & \\
\hline
\end{tabular}

Caption: Action Based Costing (ABC), Target Costing (CM), Unity of Effort Production (UEP), Theory of Restrictions (TOC) and Kaizen Costing (CK).

Source: Research data. 
We can observe that, in general, books were the main source of reference used by authors to address the topics surveyed. The use of books as reference was above $50 \%$ for all studies, regardless of the costing method. This complies with the research findings of Cruz et al. (2009), Walter et al. (2009), and Rocha, Wienhage and Scarpin (2010)

It is clear, however, that in studies about ABC, Target Costing and Kaizen Costing methods, there was greater use of sources of research from foreign journals in comparison to research that addressed TOC and UEP methodologies. In the specific case of the UEP costing method, the small use of foreign references can partly be explained by the fact that this methodology, although derived from a foreign methodology (GP method), was developed by national consultants and researchers.

\section{FINAL CONSIDERATIONS}

Costing methods are widely discussed in cost management literature; research concerning the topic, however, is dispersed, especially with regard to the period of analysis, the place of publication of studies analyzed, and the longitudinal cut, amongst other issues referring to method design. In this context, the present study aimed to compile and complement bibliometric studies presented about Activity Based Costing, Target Costing, Kaizen, Theory of Constraints and Unity of Effort Production, based on data from the first 17 editions of the Brazilian Congress of Costs (CBC).

With regard to the volume of articles published, we found that, by means of frequency distribution, the amount of articles published by event did not present normal distribution over the first 17 editions. The $\mathrm{ABC}$ method has a significantly higher number of studies compared to other costing methods analyzed. This finding may result from the topic having been recently addressed in literature and, therefore, requiring empirical research for understanding and consolidating the method.

We also observed a balance between theoretical and practical research, as well as the predominance of studies based on books. With the exception of studies about ABC, Target Costing and Kaizen, we found few studies based on international journals. In the case of UEP, this is explained in part by the fact that this method was developed by Brazilian researchers and consultants, although guided by a French proposition called the GP method.

These findings allow us to conclude that the pattern of authors dedicated to the topic remained almost unchanged. Only studies about $\mathrm{ABC}$ costing presented changes in the ranking of authors, with a larger number of articles presented in Congress when compared to the study by Diehl and Souza (2008). Thus, this study contributes to literature about cost management, especially because it demonstrates, through bibliometric analysis, the main costing methods researched and published in the Annals of the Brazilian Congress of Costs over the 1994-2010 period.

The study results, however, suggest that new research should be carried out concerning the reasons for different approaches over the examined period. Thus, for future research, we recommend that bibliometric studies, when prepared, follow a minimum standard of variables to be investigated, enabling future research to compile and expand them, as well as encouraging reflections concerning the field's publications. Nonetheless, purposes established in the study should be respected, given the particularities and different interests in studies of this nature.

\section{REFERENCES}

ANDERSON, T. R.; DAIM, T. U.; KIM, J. Technology forecasting for wireless communication. Technovation, [S.1.], v. 28, n. 9, p. 602-614, Sept. 2008.

ANDRADE, J. A. B.; MUYLDER, C. F. A relevância dos temas inovação e qualidade na pesquisa contábil: um estudo bibliométrico em eventos científicos no Brasil. ABCustos, [São Leopoldo], v. 5, n. 3, p. 43-59, Sept./Dec. 2010. 
ARAÚJO, C. A. Bibliometria: evolução histórica e questôes atuais. Em Questáo, Porto Alegre, v. 12, n. 1, p. 11-32, Jan./Jun. 2006.

BAXTER, J.; CHUA, W. F. Alternative management accounting research: whence and whither. Accounting, Organizations and Society, [S.1.], v. 28, n. 2-3, p. 97-126, Feb./ Apr. 2003.

BEUREN, I. M.; ERFURTH, A. E. Pesquisa em contabilidade gerencial com base no futuro realizada no Brasil. Contabilidade, Gestáo e Governança, Brasília, v. 13, n. 1, p. 44-58, Jan./ Apr. 2010.

BJÖRNEBORN, L.; INGWERNSEN, P. I. Toward a basic framework for webometrics. Journal of the American Society for Information Science and Technology, Hoboken, v. 55, n. 14, p. 1216-1227, Aug. 2004.

CAllado, A. L. C.; AlmeidA, M. A. A. Perfil dos artigos sobre custos no agronegócio publicados nos anais do Congresso Brasileiro de Custos. Custos e Agronegócio On-line, DLCH/UFPE, Recife, v. 1, n. 1, p. 42-61, Jan./Jun. 2005. Available at: <http://www. custoseagronegocioonline.com.br/numero1v1/ Perfil\%20de\%20publicacoes.pdf>. Access on: 07 Jul. 2011.

CLEMENTE, A. et al. Utilização de métodos quantitativos em pesquisa científica: o caso da Associação Brasileira de Custos. ABCustos, [São Leopoldo], v. 5, n. 2, p. 45-61, May/Ago. 2010.

COCHRAN, W. G. The combination of estimates from different experiments. Biometrics, Washington, D.C, v. 10, n. 1, p. 101-129, Mar. 1954.

COOPER, H. M.; ROSENTHAL, R. Statistical versus traditional procedures for summarizing research findings. Psychological Bulletin, Washington, D.C, v. 87 , n. 3, p. 442-449, May 1980 .
CRUZ, C. F. et al. Teoria das restriçôes: um estudo bibliométrico da produção científica apresentada no Congresso Brasileiro de Custos (1994-2008). ABCustos, [São Leopoldo], v. 5, n. 1, p. 132-153, Jan./Apr. 2010.

DIEHL, C. A.; SOUZA, M. A. Um estudo sobre as publicaçóes acerca do Custeio Baseado em Atividades (ABC) no Congresso Brasileiro de Custos de 1997 a 2006. Revista Contabilidade Vista e Revista, Belo Horizonte, v. 19, n. 4, p. 39-57, Oct./Dec. 2008.

FISHER, R. A. The design of experiments. Edinburgh: Oliver and Boyd, 1935.

FREZATTI, F. et al. Críticas ao orçamento: problemas com o artefato ou a não utilização de uma abordagem abrangente de análise? Revista ASAA - Advances in Scientific and Applied Accounting, Sáo Paulo, v. 3, n. 2, p. 190-216, 2010 .

GLASS, G. V. Primary, secondary, and metaanalysis of research. Educational Researcher, Washington, D.C, v. 5, n. 10, p. 3-8, Nov. 1976.

GUEDES, V.; BORSCHIVER, S. Bibliometria: uma ferramenta estatística para a gestão da informação e do conhecimento, em sistemas de informação, de comunicação e de avaliação científica e tecnológica. In: CINFORM ENCONTRO NACIONAL DE CIÊNCIA DA INFORMAÇÃO, 6., 2005, Salvador. Anais... Salvador: Universidade Federal da Bahia, 2005. Available at: < http://www.cinform.ufba.br/vi_anais/>. Acesso em: 07 Jul. 2011.

HANSEN, D. R.; MOWEN, M. M. Gestáo de custos. 3. ed. São Paulo: Pioneira Thomson Learning, 2001.

HEDGES, L. V.; OLKIN, I. Statistical methods for meta-analysis. Orlando, FL: Academic Press, 1985.

HESFORD, J. W. et al. Management accounting: a bibliographic study. Handbooks of Management Accounting Research, [S.1.], v. 1, p. 3-26, 2006. 
HOOD, W. W.; WILSON, C. S. The literature of bibliometrics, scientometrics, and informetrics. Scientometrics, Heidelberg, v. 52, n. 2, p. 291314, 2001.

HUNTER, J. E.; SCHMIDT, F. L. Methods of meta-analysis: correcting error and bias in research findings. 2. ed. Newbury Park, CA: Sage, 2004.

LOVATTO, P. A. et al. Meta-análise em pesquisas científicas: enfoque em metodologias. Revista Brasileira de Zootecnia, Piracicaba, v. 36, supl. esp., p. 285-294, 2007.

LUCENA, W. G. L.; FREIRE, R. S.; BRITO, L. A. S. N. Perfil dos artigos sobre custos voltados para área hospitalar publicados nos anais do congresso USP período de 2001-2007. Revista de Ciências Gerenciais, Valinhos, v. 14, n. 19, p. 223-238, 2010.

MACIAS-CHAPULA, C. A. O papel da informetria e da cienciometria e sua perspectiva nacional e internacional. Ciência da Informaçáo, Brasília, v. 27, n. 2, p. 233-235, maio/ago. 1998.

MAHER, M. Contabilidade de custos: criando valor para a administração. São Paulo: Atlas, 2001.

MARTINS; E.; ROCHA, W. Métodos de custeio comparados: custos e margens analisados sob diferentes perspectivas. São Paulo: Atlas, 2010.

NORONHA, D. P.; MARICATO, J. M. Estudos métricos da informação: primeiras aproximaçôes. Encontros Bibli: Revista Eletrônica de Biblioteconomia e Ciência da Informaçáo, Florianópolis, n. esp., p. 116-128, 1o sem. 2008. Available at: <https://periodicos. ufsc.br/index.php/eb/article/view/15182924.2008v13nesp1p116/1594>. Access on: 07 Jul. 2011.

OLIVEIRA, R. R.; CARVALHO, V. S.; GOMES, J. S. Produção do conhecimento por meio de publicaçóes: um estudo da produção científica dos programas de mestrado e doutorado em Ciências Contábeis no Brasil em Contabilidade de Custos e Gerencial. In: ENCONTRO DE ENSINO E PESQUISA EM ADMINISTRAÇÃO E CONTABILIDADE, 2., 2009, Curitiba. Anais... Rio de Janeiro: ANPAD, 2009. Available at: <http://www.anpad. org.br/evento.php?acao=trabalho\&cod_edicao_ subsecao $=513 \&$ cod_evento_edicao $=47 \& \operatorname{cod}$ edicao_trabalho $=11168 \#$ self $>$. Access on: 07 jul. 2011.

OSWALD, F. L.; PLONSKY, L. Meta-analysis in second language research: choices and challenges. Annual Review of Applied Linguistics, Cambridge, v. 30, p. 85-110, Mar. 2010.

OYADOMARI, J. C. et al. Fatores que influenciam a adoção de artefatos de controle gerencial nas empresas brasileiras: um estudo exploratório sob a ótica da teoria institucional. Revista de Contabilidade e Organizaçóes, Ribeirão Preto, v. 2, n. 2, p. 55-70, Jan./Apr. 2008.

RIERA, R.; ABREU, M. M. A.; CICONELLI, R. M. Revisões sistemáticas e metanálises na reumatologia. Revista Brasileira Reumatologia, São Paulo, v. 46, supl. 1, p. 8-11, Jun. 2006.

ROCHA, D. T. et al. Gestão de custos: um estudo bibliométrico e sociométrico da produção científica do EnANPAD 1997-2008. In: CONGRESSO BRASILEIRO DE CUSTOS, 17., 2010, Belo Horizonte. Anais... São Leopoldo: ABC, 2010. Disponível em: <http://www.abcustos.org.br/ texto/viewpublic?ID_TEXTO=3192>. Available at: 07 Jul. 2011.

ROCHA, I.; WIENHAGE, P.; SCARPIN, J. E. Investigação da produção científica relacionada ao custeio-meta e custeio kaizen no período de 2002 a 2009. Contexto, Porto Alegre, v. 10, n. 18, p. 75-86, 2. Sem. 2010.

ROSENTHAL. R. Combining results of independent studies. Psychological Bulletin, Washington, D.C, v. 85, n. 1, p.185-193, Jan. 1978 . 
SCHMIDT, F. L.; HUNTER, J. E. Development of a general solution to the problem of validity generalization. Journal of Applied Psychology, Washington, D.C, v. 62, n. 5, p. 529-540, Oct. 1977.

SMITH, M. L.; GLASS, G. V. Meta-analysis of psychotherapy outcome studies. American Psychologist, Washington, D.C, v. 32, n. 9, p. 752-760, Sept. 1977.

SCHULTZ, C. A. et al. Produção científica na área de custos no setor de serviços no período de 2000 a 2004. In: CONGRESSO USP DE
CONTABILIDADE E FINANÇAS, 6., 2006, São Paulo. Anais... São Paulo: FEA/USP, 2006. Available at: <http://www.congressousp.fipecafi. org/index.aspx\#>. Access on: 07 Jul. 2011.

WALTER, F. et al. O perfil dos artigos sobre o método das UEPs nos anais do Congresso Brasileiro de Custos e do Encontro Nacional de Engenharia de Produção. In: CONGRESSO BRASILEIRO DE CUSTOS, 16., 2009, Fortaleza. Anais... São Leopoldo: ABC, 2009. Available at: <http://www.abcustos.org.br/texto/ viewpublic?ID_TEXTO=3076>. Access on: 07 jul. 2011. 